\title{
Coordination of Marine Functional Zoning Revision at the Provincial and Municipal Levels: A Case Study of Putian, China
}

\author{
Faming Huang ${ }^{1, *}$, Yanhong Lin ${ }^{1,2}$, Huixin Liang ${ }^{2}$, Rongrong Zhao ${ }^{1}$, Qiuming Chen ${ }^{1}$, Jie Lin ${ }^{1}[$ \\ and Jinliang Huang ${ }^{2, *}$ \\ 1 Third Institute of Oceanography, Ministry of Natural Resources, Xiamen 361005, China; \\ linyanhong@tio.org.cn (Y.L.); zhaorongrong@tio.org.cn (R.Z.); chenqiuming@tio.org.cn (Q.C.); \\ linjie@tio.org.cn (J.L.) \\ 2 College of the Environment and Ecology, Xiamen University, Xiamen 361005, China; joyliang0202@163.com \\ * Correspondence: huangfaming@tio.org.cn (F.H.); jlhuang@xmu.edu.cn (J.H.); Tel.: +86-592-219-5001 (F.H.)
}

Received: 11 October 2019; Accepted: 22 November 2019; Published: 3 December 2019

check for updates

\begin{abstract}
Marine functional zoning (MFZ) is a type of marine spatial planning (MSP) implemented widely in China and one of the three major systems defined in the Law of the PRC on the Administration of Sea Area Use. China adopts "top-down management" for MFZ, in which upper management levels impose clear constraints and restrictions on lower levels. However, this approach has led to issues, such as a rigid MFZ classification system and unreasonable re-allocation of control indicators in the process of assigning MFZ classification at different levels. In this study, we propose and demonstrate the coordination of MFZ revision in terms of the classification system and the re-allocation of control indicators in the coastal city of Putian, China. The results show that the proposed measures could help realize the effective and reasonable coordination of MFZ revisions at the provincial and municipal levels, providing a reference for such MFZ revisions in other regions of China and the coordination of MSP between different levels in other countries.
\end{abstract}

Keywords: marine functional zoning; establishment coordination; classification system; control indicators

\section{Introduction}

Major coastal countries mostly implement marine management using marine spatial planning (MSP). The application of MSP can help resolve conflicts between human activities and limited maritime resources by regulating the spatial and temporal distribution of human behavior, thereby promoting the realization of marine management based on the marine ecosystem [1-3]. Various instances of MSP have been successfully implemented globally, including the 2004 rezoning of the Great Barrier Reef Marine Park in Australia and the 2008 Ocean Space Program in the European Union [4,5]. In China, marine functional zoning (MFZ) is a major implementation of MSP as one of the three major systems defined in the Law of the People's Republic of China (PRC) on the Administration of Sea Area Use.

Most western maritime countries, such as the United States, Australia, and the United Kingdom, have adopted "bottom-up" management, in which higher government levels act only to guide the strategy and policy implementations of the lower levels [6]. For example, the MSP in the United States is divided into three levels: Federal, regional, and state. The social, cultural, political, and administrative boundaries of natural ecosystems must be considered to determine the scope of different marine spaces [7]. Regional management is the management mode of its MSP. At the regional level, the national sea area is divided into nine regions, and each region has its own independent planning agency to formulate its own MSP. In the case of a regional overlap, the two regions send representatives 
of each negotiate the completion of the planning [8]. Unlike the abovementioned countries, the Chinese government applies a "top-down" strategy for marine management in which most decision-making power is held by the state council at the highest levels of government, who are responsible for re-allocating resources and resolving conflicts between different departments. To realize top-down control of the sea area, the current MFZ is divided into three levels that comprehensively cover the entire marine territory of China [9] as follows:

1. First level: According to physical geography characteristics, China's offshore area is divided into five geographic regions: The Bohai Sea, Yellow Sea, East China Sea, South China Sea, and Taiwan Straits. First-level zoning determines the overall management requirements of the sea area [10].

2. Second level: The MFZ at the provincial-level coastal area is formulated, and the sea area is divided into several concrete marine functional zones according to the characteristics of the mesoscale marine area and the geographical division for the rational development of the marine economy in the different provinces [11].

3. Third level: According to the spatial layout of marine development at the provincial level and the different characteristics of natural resources and environment in the sea area of each city, the MFZ at the municipal level is formulated within the scope of the provincial-level MFZ. The MFZ at both the provincial and municipal levels divide the marine area into 8 primary classification and 22 secondary classification basic marine functional zones [11].

Comparatively speaking, China's MFZ system has obvious advantages, including a high legal status and wide implementation level [12]. However, China's top-down management has led to the following issues related to the MFZ formulation and implementation processes [13]:

1. Low applicability: The current MFZ with two classifications has defects because it is not suitable for local specific marine management. The current MFZ at provincial and municipal levels only divides the sea area into two classifications: Primary classification and secondary classification (Table 1). However, for specific sea area management activities, a classification system with only two classifications obviously cannot meet the needs of China's local government for sea area management; the local government needs a more detailed classification system. Therefore, the absence of a detailed classification system at the provincial level makes the current MFZ approach less adaptable.

2. Deficient rationality: China's MFZ at the provincial level determines the total area of the reclamation zone and fishery farming zone in each province using a standardized form. Furthermore, the MFZ system requires each level to adopt the control indicators (including the area of reclamation zone, fishery farming zone, reserve zone, marine protected zone, and natural coastline retention rate) of the higher level. The current solution to reallocate area control indicators from the provincial level to the municipal level will lead to the distribution of the control value of the province equally to each city, which is unreasonable. Therefore, a reasonable solution should be designed in this research.

The Chinese government launched a third round of MFZ revision in 2012 [14,15]. Facing the need for increasingly detailed marine management, the formulation and implementation of the MFZ system at the municipal level has become a key link in China's MSP. Very few theoretical studies have investigated coordination between the upper and the lower levels of the MSP or MFZ under "top-down" management. At present, there is no established reference on coordination between the upper and lower levels of China's MFZ system. The objectives of this study are therefore to coordinate the MFZ classification system at the provincial and municipal levels, and to re-allocate the control indicators at the provincial level to the municipal level. We then demonstrate the effectiveness of the proposed solution in a coastal city in China. The results of this study can be used to revise the MFZ system to achieve improved coordination between provincial and municipal levels. 
Table 1. Current MFZ classification system.

\begin{tabular}{|c|c|}
\hline Primary Classification & Secondary Classification \\
\hline 1. Agriculture and Fishery Zone & $\begin{array}{l}\text { 1.1. Agricultural Reclamation Zone } \\
\text { 1.2. Aquaculture Zone } \\
\text { 1.3. Proliferation Zone } \\
\text { 1.4. Fishing Zone } \\
\text { 1.5. Aquatic Germplasm Resources Protected Zone } \\
\text { 1.6. Fishery Infrastructure Zone }\end{array}$ \\
\hline 2. Port Shipping Zone & $\begin{array}{l}\text { 2.1. Port Zone } \\
\text { 2.2. Channel Zone } \\
\text { 2.3. Anchor Zone }\end{array}$ \\
\hline 3. Industrial and Urban Zone & $\begin{array}{l}\text { 3.1. Industrial Sea Zone } \\
\text { 3.2. Urban Zone }\end{array}$ \\
\hline 4. Mineral and Energy Zone & $\begin{array}{l}\text { 4.1. Oil and Gas Zone } \\
\text { 4.2. Solid Mineral Zone } \\
\text { 4.3. Salt Zone } \\
\text { 4.4. Renewable Energy Zone }\end{array}$ \\
\hline 5. Tourism and Entertainment Zone & $\begin{array}{l}\text { 5.1. Tourist Scenic Zone } \\
\text { 5.2. Recreation Zone }\end{array}$ \\
\hline 6. Marine Protected Zone & $\begin{array}{l}\text { 6.1. Marine Nature Protected Zone } \\
\text { 6.2. Marine Special Protected Zone }\end{array}$ \\
\hline 7. Special Use Zone & $\begin{array}{l}\text { 7.1. Military Zone } \\
\text { 7.2. Other Special Use Zone }\end{array}$ \\
\hline 8. Reserved Zone & 8.1. Reserved Zone \\
\hline
\end{tabular}

\section{Methodology}

\subsection{Study Area}

The city of Putian is located in the middle of the coastal area of Fujian Province, on the eastern shores of the Taiwan Strait $\left(24^{\circ} 55^{\prime}-25^{\circ} 45^{\prime}, 118^{\circ} 41^{\prime}-120^{\circ} 05^{\prime}\right)$ (Figure 1). It contains 11 residential islands, 146 uninhabited islands, and 461 reefs. The length of the island coastline is approximately $107 \mathrm{~km}$. Putian City has three major bays: Xinghua Bay (South Shore), Pinghai Bay, and Meizhou Bay (North Shore). The city has a rich culture, and its marine economic system has recently been developed to include marine fisheries, the port shipping industry, and the coastal tourism industry. However, this development has faced several challenges: These marine industries have not developed readily because port infrastructure cannot satisfy the necessary requirements, the science and technology are not sufficiently developed to support the marine industry, the carrying capacity of the natural resources and environment is limited, and the marine management system needs to be further established. As these problems can be observed in most coastal cities in China in some form or another, Putian City is considered as the case study in this research. 


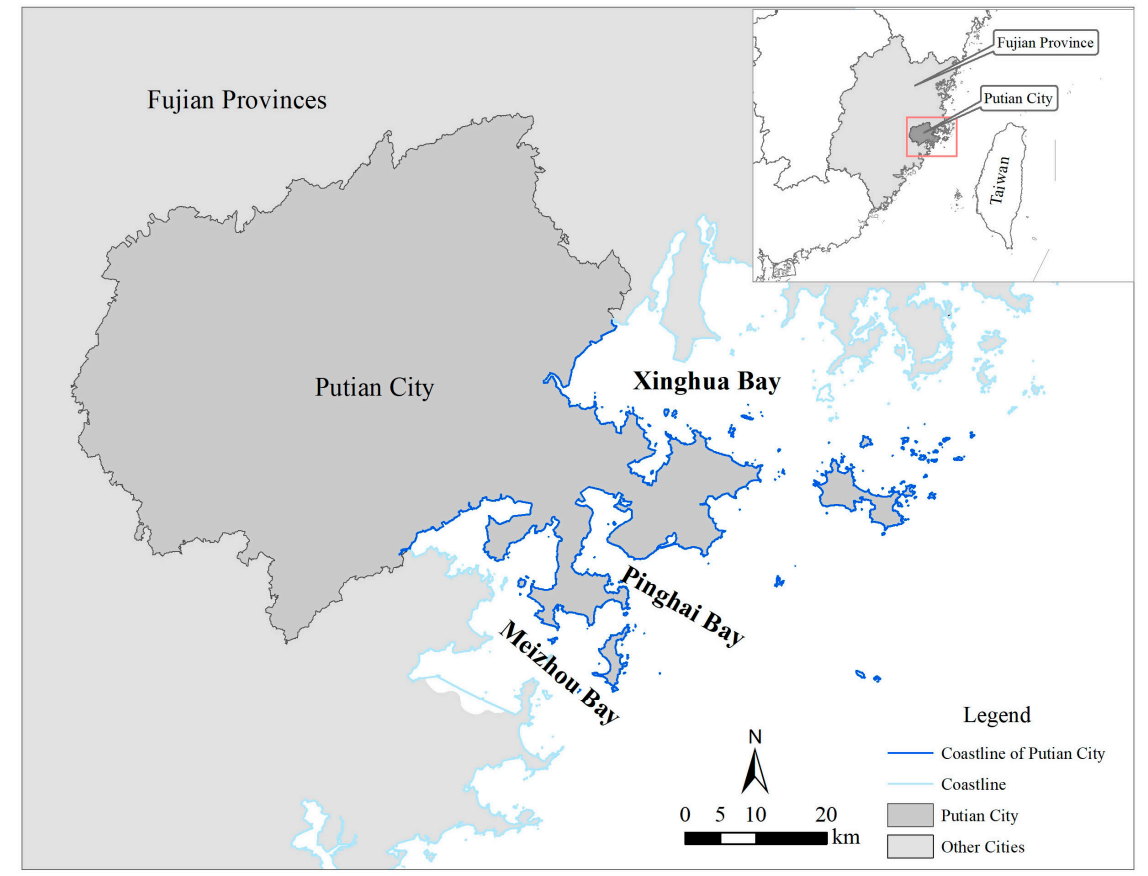

Figure 1. Location of Putian City, Fujian Province, China.

\subsection{Research Methods and Framework}

The process of revising the MFZ was divided into three phases as shown in Figure 2. First, materials related to the MFZ of the study area were collected, including China's MFZ management regulations, planning documents, the current status of sea area use (SAU), and the resources and environmental conditions. These data were then analyzed to determine the scope of the key fields to be investigated. Second, the MFZ classification system at the provincial level was analyzed, and the main problems and associated feasible improvements to the current MFZ were identified using the results of an expert survey (all experts invited to this survey were working in marine-related fields, and they all had been engaged in relevant employment for more than eight years). Third, the natural and social attributes of different sea areas were compared considering the expert suggestions and a mathematical model. Finally, we proposed MFZ coordination measures for the provincial and municipal levels.

China's MFZ control system is composed of an MFZ classification system and control indicators. The MFZ classification system uses a classification model to define the spatial layout of sea area usage types according to comprehensive consideration of marine nature, environment, ecology, economic, social, and ocean security requirements [16]. China's current MFZ classification system is divided into 8 primary and 22 secondary MFZ classifications, as listed in Table 1. Fujian Province has developed MFZ based on this provincial classification (Figure 3). The control indicators are used to fix the scale and intensity of these SAUs for the area of the reclamation zone, fishery farming zone, reserved zone, and marine protected zone, as well as the natural coastline retention rate. This quantitative value clearly defines the expected and possible use during the zoning period. The overall result is that the marine development activities are binding and can be tracked [17]. Combined, these measures work to supervise the development and utilization of the sea area to reduce the resulting impact on the marine environment [17]. 

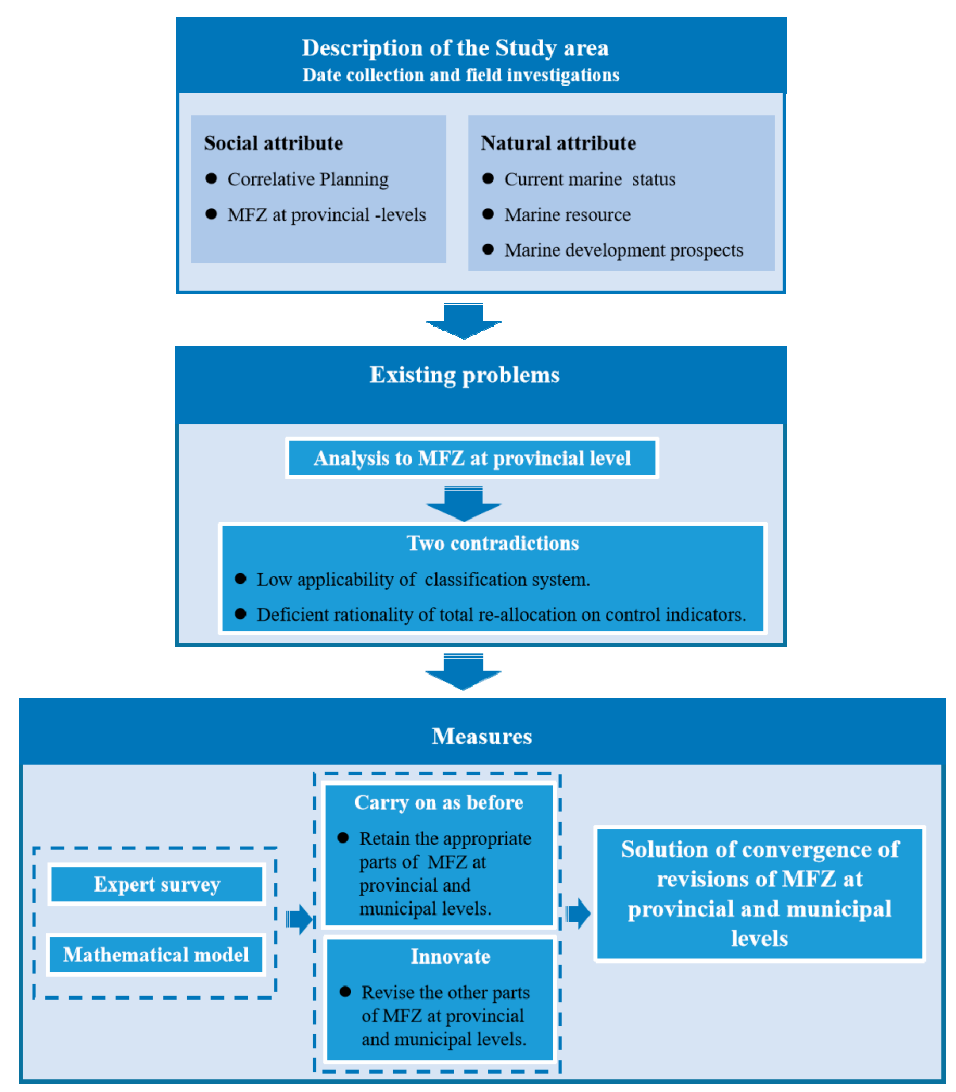

Figure 2. Framework of the MFZ revision process.

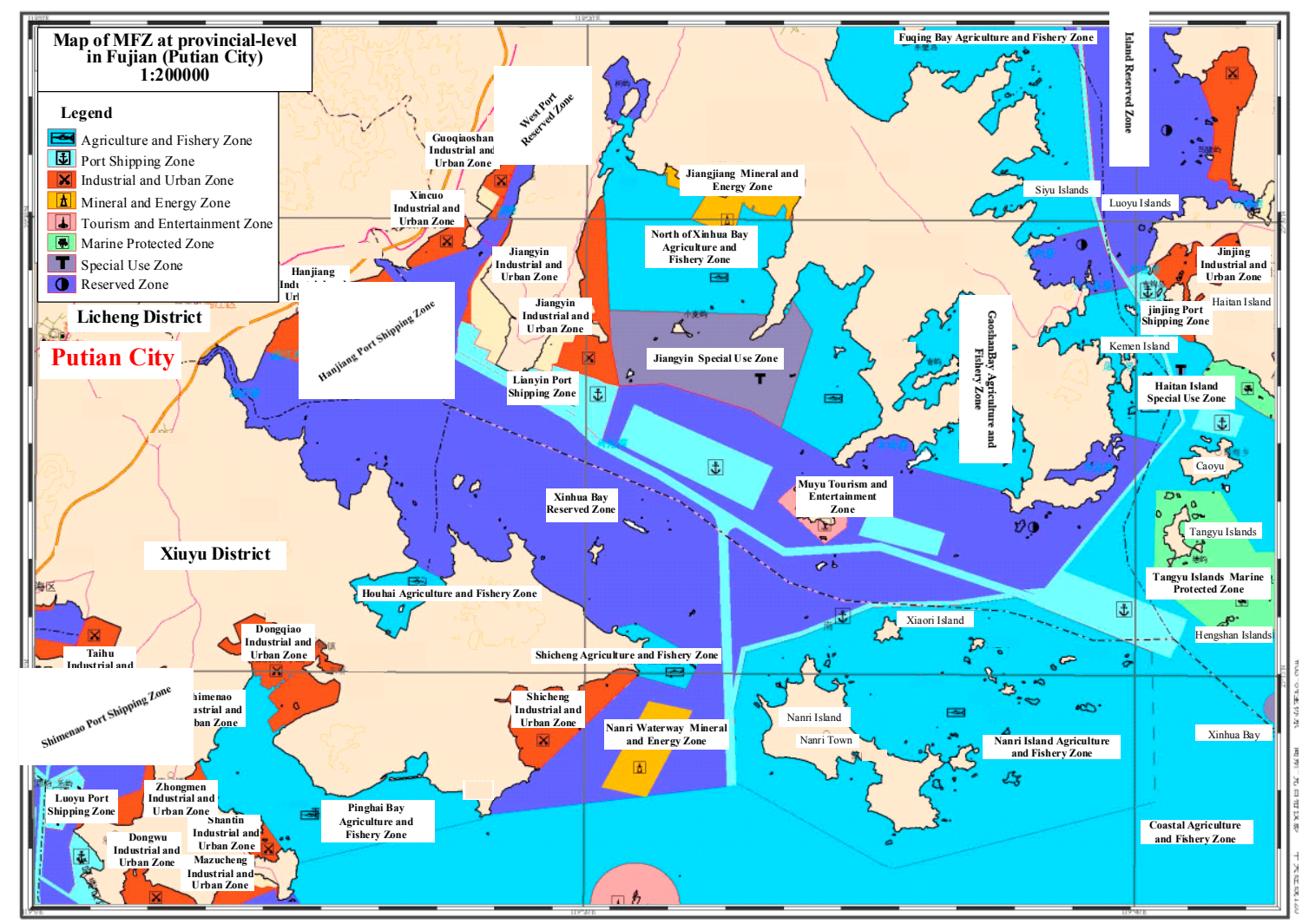

Figure 3. Map of provincial-level MFZ in Fujian (Putian City). 


\subsubsection{Expert Survey}

The expert survey method was first adopted in the authors' research [18-20]. Forty-eight experts and managers (Table 2) who were well informed on the sea area status of Putian City or the MSP in general were invited to participate in the investigation by completing questionnaires. These experts were affiliated with the National Oceanographic Research Institute, the local marine research institute, various universities, and local government departments. Their areas of expertise were marine science, and all had been engaged in relevant employment for more than eight years. Furthermore, we invited managers who come from the grassroots level of the government and who had long been engaged in sea area management. They are very knowledgeable about the situation of the local sea area and the demands of the stakeholders. As a result, stakeholder concerns have been covered in our survey.

Table 2. Expert basic information list.

\begin{tabular}{llc}
\hline \multicolumn{1}{c}{ Expertise/Affiliation } & Number of Participants \\
\hline \multirow{5}{*}{ Experts } & 18 \\
& Marine management & 8 \\
& Marine biological resources and environment & 2 \\
& Marine geology & 1 \\
& Watershed management & 2 \\
& Marine chemistry & 4 \\
& Marine biology & 1 \\
\hline \multirow{5}{*}{ Environmental science } & 5 \\
& District government & 2 \\
& Marine Bureau & 1 \\
& Maritime Bureau & 1 \\
& Transportation Bureau & 1 \\
& Environmental Protection & 1 \\
& Development and Reform Commission & 1 \\
\hline
\end{tabular}

Notes: One government manager each from the Hanjiang District, Chengxiang District, Xiuyu District, Licheng District, and Xianyou County governments was invited to participate.

To conduct the survey, we conducted a three-day workshop in Putian City between 27 and 29 October 2014. The questionnaire was sent to the experts by email to complete one week before the workshop. At the workshop, we presented a comprehensive overview of the answers they provided to the questionnaire. Then, the experts were asked to explain the content of the questionnaire and were encouraged to debate on controversial issues. Our workshop focused on the coordination of revisions to the MFZ at the provincial and municipal levels, with the objective of reaching an agreement and forming a coordination framework among the experts. During the seminar, 8 out of 48 participants were interviewed by our researchers, and they provided more detailed suggestions and their previous research experience to complement our review.

The questionnaire (shown in Appendix A) was comprised of three sections. The first section primarily focused on collecting information describing the participant's profession, level of experience, and length of relevant employment. The second section contained four open-ended questions related to this study with the objective of identifying: Q1, the main problems in the coordination of MFZ revisions at the provincial and municipal levels; Q2, the inadequacies in the current MFZ classification system and potentially feasible improvements; Q3, the specific functional areas that need to be improved, added, or deleted from the revised Putian City MFZ; and Q4, suggestions for re-allocating MFZ control indicators at the provincial and municipal levels. The third section investigated the participant's current or previous experience with specific MFZ or MSP to understand the research background of the participants and learn from their experience and suggestions [21,22]. 


\subsubsection{Mathematical Model}

As control indicators at the MFZ, the area of the reclamation zone, fishery farming zone, reserve zone, and marine protected zone were determined as a fixed value. According to the "Marine Function Zoning in Fujian Province (2011-2020)", the sea reclamation area at the provincial level should be controlled to within $33,350 \mathrm{hm}^{2}$ by 2020 , the fishery farming area will be greater than $153,000 \mathrm{hm}^{2}$, marine protected area will be greater than $11.9 \%$ of the total zoning area, and the reserved area will not be less than $10 \%$ of the total area [23]. The scale of the above control indicators must be severely restricted [24]. Because marine development and marine-dominant industries vary in different areas, the MFZ control indicators at the municipal level should not be averaged according to the MFZ control values at the provincial level but were forecast according to different possible situations. The sea reclamation area and fishery farming area were selected as control indicators for Putian City. First, like other coastal cities of China, Putian City has been driven by the accelerating socio-economic development to undergo extensive reclamation to deal with its insufficient land space. In addition, the marine fishery in Putian City is an important part of local marine economy, which has therefore attracted the attention of the local governor.

\section{(1) Accounting for the control indicator of the area of reclamation zone}

We assumed that experts' advice would result in more reasonable re-allocation schemes for control indicators. Based on this advice, both the reclamation potential assessment method and the proportional growth method were developed to address the re-allocation of the control indicators [25]. First, according to the author's research results on the reclamation intensity index (RII) in 2011, RII was used as the restrictive index of the reclamation, which can be used for the control of the reclamation scale [26]. Therefore, the reclamation potential assessment method was used to provide a comprehensive evaluation of reclamation needs; this method requires simple calculations to determine the full reclamation potential of a certain area and arrange the development time sequentially. Second, the proportional growth method is also relatively simple and requires only a single calculation to determine the area of reclamation demand. Therefore, the predictions from the comprehensive reclamation potential assessment method and the proportional growth method were both evaluated, and their average value was taken as the allowed value of the reclamation area.

First, the reclamation potential assessment method was used to assess the main reclamation projects in the study area over the past 10 years and calculate the reclamation intensity accordingly. Then, the reclamation intensity was used to judge the reclamation potential of the region in the future. The reclamation intensity was determined using [25,27]:

$$
R=\frac{S_{\mathrm{T}}}{L},
$$

where $R$ is the reclamation intensity index, $S_{\mathrm{T}}\left(\mathrm{hm}^{2}\right)$ is the area reclaimed in a year, and $L(\mathrm{~km})$ is the unit shoreline length. Based on the analysis of the correlation between RII and the comprehensive evaluation index of the main bays in Fujian Province, China, the values of reclamation strength were classified, as listed in Table 3 [26]. When $R \geq 50$, sea reclamation should be focused on saving and intensive use. To avoid excessive use of the sea area, the authors suggest that when calculating the allowable reclamation area, $R<50$ should be the control value. If the reclamation intensity is lower than Grade III, the reclamation pressure is affordable, and the impact on the coastal ecological health is inapparent. Therefore, the reclamation intensity of Grade III ( $50 \mathrm{hm}^{2}$ per kilometer of coastline) was chosen as the critical level for ensuring the environmental health of coastal resources. In this case, the maximum reclamation area that can be accommodated by the reclamation intensity of Grade III is used as the reclamation supply potential. The potential reclamation can be calculated as $[25,28]$ :

$$
P=S_{\mathrm{III}}-S,
$$


where $P\left(\mathrm{hm}^{2}\right)$ is the potential reclamation, $S_{\text {III }}\left(\mathrm{hm}^{2}\right)$ is the largest affordable reclamation capacity for Grade III, and $S\left(\mathrm{hm}^{2}\right)$ is the current reclamation volume.

Table 3. Scale of the reclamation intensity index.

\begin{tabular}{|c|c|c|}
\hline$R\left(\mathrm{hm}^{2} \cdot \mathrm{km}^{-1}\right)$ & Strength Grade & Description \\
\hline $0 \leq R \leq 10$ & $\mathrm{I}$ & Slight reclamation pressure and great potential for development \\
\hline $10 \leq R<20$ & II & Low reclamation pressure and certain potential for development \\
\hline $20 \leq R<50$ & III & $\begin{array}{c}\text { Certain reclamation pressure and influence for } \\
\text { further development }\end{array}$ \\
\hline $50 \leq R \leq 100$ & IV & $\begin{array}{c}\text { Strong reclamation pressure; sea reclamation should be focused on } \\
\text { saving and intensive use }\end{array}$ \\
\hline$R \geq 100$ & V & $\begin{array}{c}\text { Very strong reclamation pressure; new reclamation projects } \\
\text { should not be allowed, and if necessary existing reclamation area } \\
\text { should be filled. }\end{array}$ \\
\hline
\end{tabular}

Notes: adapted from [26], with permission from Journal of subtropical resources and environment, 2013.

Next, a regression equation was calculated according to the historical data of the region for the linear regression analysis. The total reclamation area $\left(S_{1}\right)$ was then predicted using the linear regression analysis.

Third, according to China's "Measures for the Management of Reclamation Plans" issued in December 2011, the amount of reclamation should not exceed $15 \%$ of the annual average of the last three years of land reclamation [29]. Therefore, 15\% was used as the growth indicator for future reclamation, and the total area of reclamation $\left(S_{2}\right)$ was predicted by the proportional growth method using the following equations [25]:

$$
\begin{gathered}
S_{\mathrm{An}}=k \cdot S_{\mathrm{A}(\mathrm{n}-1)}, \\
S_{\mathrm{I}}=S_{\mathrm{A} 1}+S_{\mathrm{A} 2}+\cdots+S_{\mathrm{An}}, \\
S_{2}=S+S_{\mathrm{I}},
\end{gathered}
$$

where $S_{\mathrm{An}}\left(\mathrm{hm}^{2}\right)$ is the predicted approved reclamation area for year $\mathrm{n}, k\left(\mathrm{hm}^{2}\right)$ is the percentage of the annual increase in the approved reclamation area, $S_{2}\left(\mathrm{hm}^{2}\right)$ is the total predicted reclamation area according to the proportional growth method, and $S_{\mathrm{I}}\left(\mathrm{hm}^{2}\right)$ is the predicted increase in reclamation area.

(2) Accounting for the control indicator of the fishery farming zone

The same method as that used to forecast the total reclamation area, regression analysis was used to predict the value of the fishery farming area control indicator. The regression function model was established using the trend of the fishery farming area statistics in the region over the past 10 years and used to quantitatively predict the mariculture area in future years. In this manner, the fishery farming area $\left(S_{\mathrm{F}}\right)$ was predicted from the historical data of the region using linear regression analysis.

\section{Results}

\subsection{Coordination of MFZ Classification System at the Provincial and Municipal Levels.}

A summary of the opinions of the survey respondents and the authors' attitudes toward them are listed in Table 4. It can be seen that the expert opinions focus on the answers to the three questions Q1, Q2, and Q4, while the comments of government managers focused on the answer to Q3 because they were more familiar with the various situations of different sea areas. 
Table 4. Summary of the opinions of participants of MFZ in Putian City.

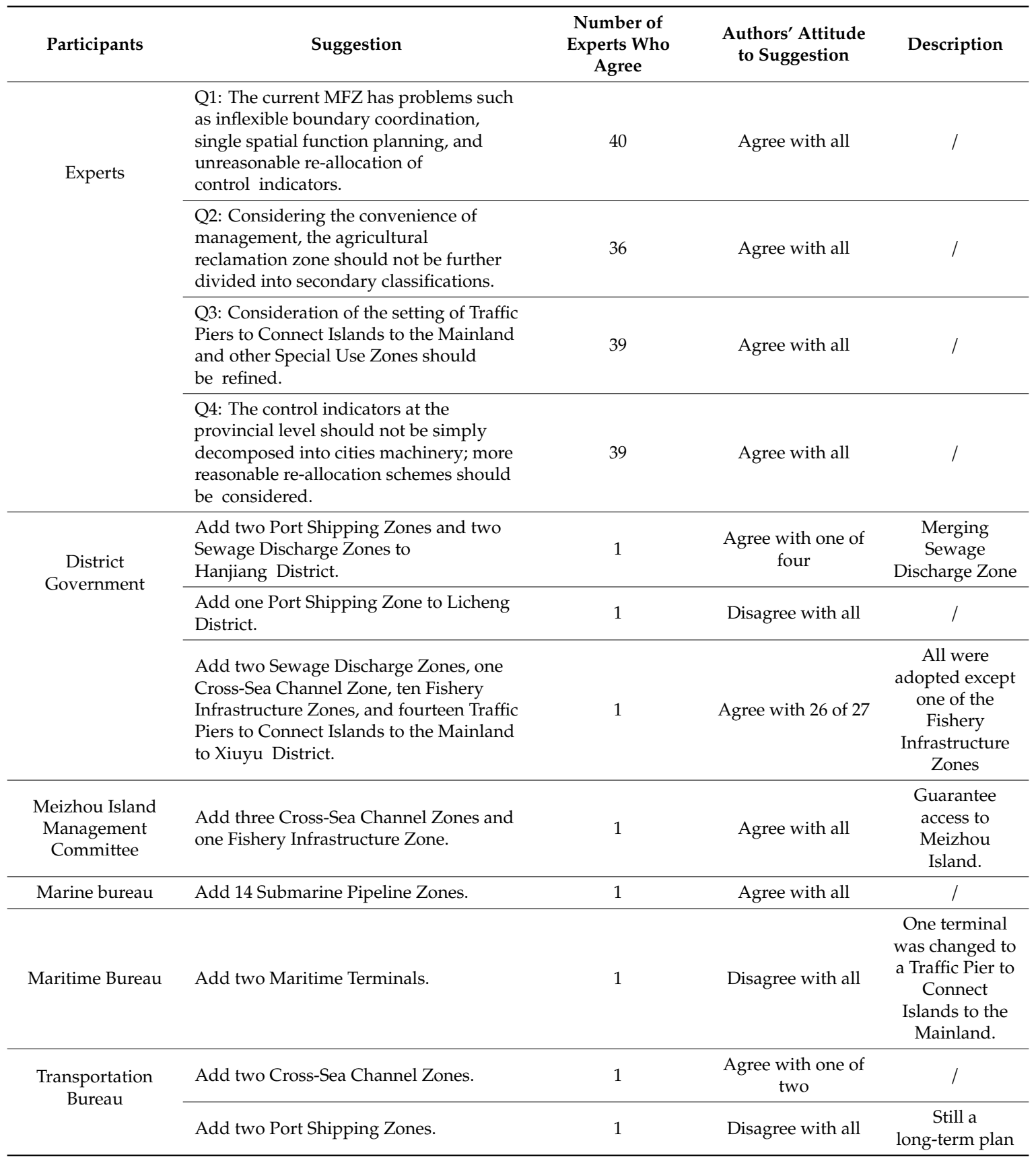

\footnotetext{
Notes: (a) The added fishing port was determined according to The Layout and Construction Plan of the Fishing Port of Offshore Fujian province (2009-2018); (b) The unlisted government departments in this table did not express their opinions.
}

According to the results of the expert survey, the current MFZ classification system with 8 primary classifications and 22 secondary classifications was optimized at the provincial level (Table 1). As a result, a new classification system with 23 secondary was developed. Furthermore, the other Special Use Zones was further divided into four tertiary marine functional zones (Table 5). The specific divisions are as follows. 
Table 5. New MFZ classification system.

\begin{tabular}{|c|c|c|c|c|c|c|}
\hline \multicolumn{2}{|c|}{ Primary Basic Marine Functional Area } & \multicolumn{4}{|c|}{ Secondary Basic Marine Functional Area } & \multirow{2}{*}{$\begin{array}{l}\text { Current MFZ Revision } \\
\text { Using Secondary Indicators }\end{array}$} \\
\hline NO. & Name & NO. & Name & & & \\
\hline 1 & $\begin{array}{l}\text { Agriculture and } \\
\text { Fishery Zone }\end{array}$ & $\begin{array}{l}1.1 \\
1.2 \\
1.3 \\
1.4 \\
1.5 \\
1.6\end{array}$ & $\begin{array}{l}\text { Agricultural Recla } \\
\text { Aquaculture Zone } \\
\text { Proliferation Zone } \\
\text { Fishing Zone } \\
\text { Aquatic Germplas } \\
\text { Fishery Infrastruct }\end{array}$ & $\begin{array}{l}\text { on Zone } \\
\text { sources Protected Zone } \\
\text { Zone }\end{array}$ & & $\begin{array}{l}\text { Classification inherits the primary classification } \\
\text { of agriculture and fisheries without division }\end{array}$ \\
\hline \multirow[t]{2}{*}{2} & \multirow[t]{2}{*}{ Port Shipping Zone } & $\begin{array}{l}2.1 \\
2.2 \\
2.3\end{array}$ & $\begin{array}{l}\text { Port Zone } \\
\text { Channel Zone } \\
\text { Anchor Zone }\end{array}$ & & & \multirow[b]{2}{*}{$\begin{array}{l}\text { Added secondary classification division for } \\
\text { certain functional zoning }\end{array}$} \\
\hline & & 2.4 & \multicolumn{3}{|c|}{$\underline{\text { Traffic Pier to Connect Land and Island }}$} & \\
\hline 3 & $\begin{array}{l}\text { Industrial and Urban } \\
\text { Zone }\end{array}$ & $\begin{array}{l}3.1 \\
3.2\end{array}$ & \multicolumn{3}{|l|}{$\begin{array}{l}\text { Industrial Sea Zone } \\
\text { Urban Zone }\end{array}$} & No secondary classification division \\
\hline 4 & $\begin{array}{l}\text { Mineral and Energy } \\
\text { Zone }\end{array}$ & $\begin{array}{l}4.1 \\
4.2 \\
4.3 \\
4.4\end{array}$ & \multicolumn{3}{|c|}{$\begin{array}{l}\text { Oil and Gas Zone } \\
\text { Solid Mineral Zone } \\
\text { Salt Zone } \\
\text { Renewable Energy Zone }\end{array}$} & No secondary classification division \\
\hline 5 & $\begin{array}{l}\text { Tourism and } \\
\text { Entertainment Zone }\end{array}$ & $\begin{array}{l}5.1 \\
5.2\end{array}$ & \multicolumn{3}{|l|}{$\begin{array}{l}\text { Tourist Scenic Zone } \\
\text { Recreation Zone }\end{array}$} & No secondary classification division \\
\hline 6 & $\begin{array}{l}\text { Marine Protected } \\
\text { Zone }\end{array}$ & $\begin{array}{l}6.1 \\
6.2\end{array}$ & \multicolumn{3}{|c|}{$\begin{array}{l}\text { Marine Nature Protected Zone } \\
\text { Marine Special Protected Zone }\end{array}$} & No secondary classification division \\
\hline 7 & Special Use Zone & 7.2 & $\begin{array}{l}\text { Military Zone } \\
\text { Other Special Use } \\
\text { Zones }\end{array}$ & $\begin{array}{l}7.2 .1 \\
7.2 .2 \\
7.2 .3 \\
7.2 .4\end{array}$ & $\begin{array}{l}\frac{\text { Sewage Discharge Zone }}{\text { Cross-Sea Channel Zone }} \\
\text { Submarine Pipeline Zone } \\
\text { Dumping Waste Zone }\end{array}$ & $\begin{array}{l}\text { Classified into four tertiary classifications } \\
\text { considering the secondary classification, } \\
\text { including sewage, submarine pipeline, bridge } \\
\text { tunnel, dumping, and other uses }\end{array}$ \\
\hline 8 & Reserved Zone & 8.1 & Reserved Zone & & & No secondary classification division \\
\hline
\end{tabular}

Note: Underlined text indicates an adjustment to the MFZ by adding a secondary or tertiary classification. 
First, in the provincial classification system, the secondary functional zones in the Agricultural and Fishery Zone focus on social attributes and consider human activities. In fact, most Agricultural and Fishery Zones have a relatively wide area, and their secondary functional zones only cover offshore areas. However, the original areas far from these offshore zones could not be defined independently. Therefore, there is no further division to the secondary classifications in municipal zoning, and only Fishery Infrastructure Zones are set up for fishing ports.

Second, in the provincial classification system, the Port Shipping Zone was divided into three secondary functional zones: Port Zone, Channel Zone, and Anchorage Zone. Among these, the Port Zone is defined as "the area in which ships can berth, load, and unload, and take shelter from the wind, including the harbor pools, wharfs, and warehouses". The MFZ at the provincial level now includes the Traffic Pier to Connect Islands to the Mainland Zone as part of the Port Zone. However, as such traffic piers consist of a small wharf and its supporting facilities that provide public transportation services for island residents and tourism, this configuration is not consistent with the definition of a port zone. Therefore, the traffic pier to connect islands to the mainland was added to the Port Shipping Zone as a secondary classification functional zone. A total of 19 Traffic Pier to Connect Islands to the Mainland Zones were thus added to the MFZ of Putian City.

A typical example of Traffic Pier to Connect Islands to the Mainland Zone is the Nanri Island Traffic Pier (Figure 4), which was established to satisfy the transportation needs of residents, ensure smooth flow in the navigation channel, and facilitate regular construction of the port. Furthermore, in this area, changing the natural attributes of the sea area is prohibited except for the necessary construction of wharfs and ship docking facilities. This is to maintain the water depth at the front of the wharfs, and to meet the navigation needs of the ships.

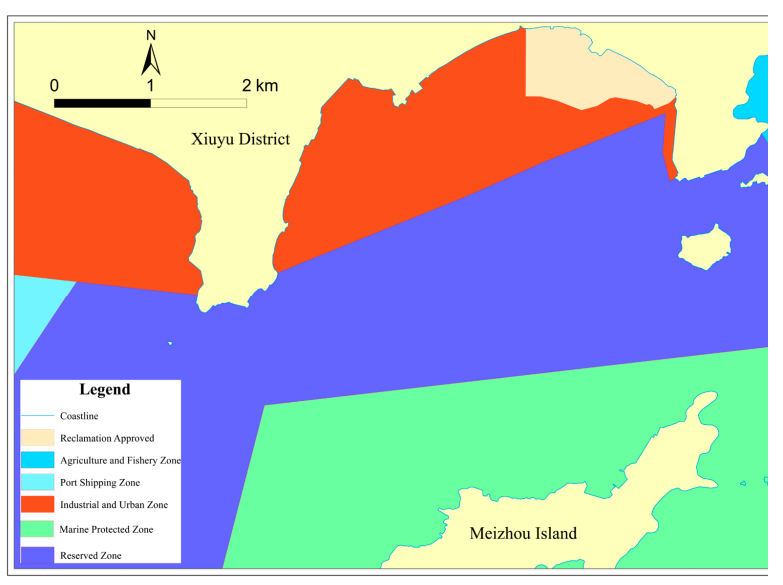

(a) original zoning

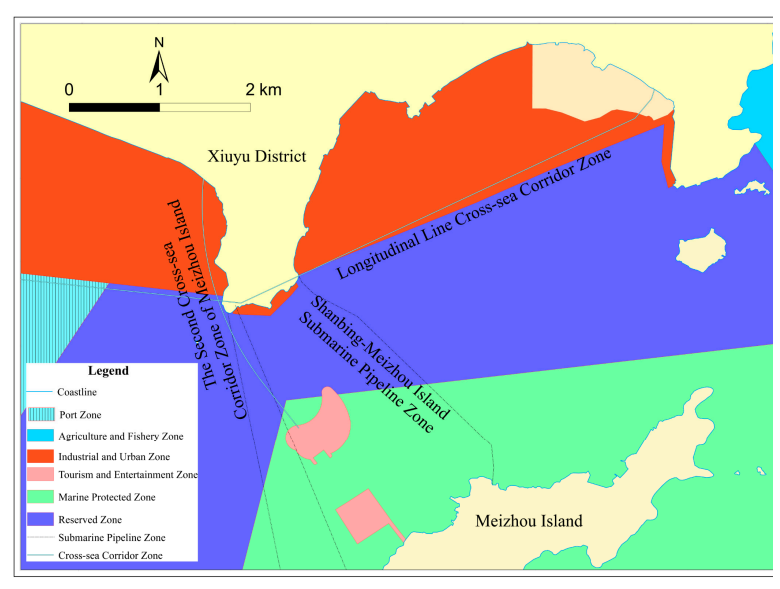

(b) modified zoning

Figure 4. Revised zoning (a) provincial zoning, (b) municipal zoning.

Third, the "Technical Requirements for the Formulation of Marine Functional Zoning" at the provincial level stipulates that Special Use Zones, such as sewage outlets, bridges, tunnels, and submarine pipelines, are not to be established in the MFZ at the provincial level. However, the above-mentioned Special Use Zones could be established in the MFZ at the municipal level because of the need for increasingly detailed marine management. This suggests that the Sewage Discharge Zone, Submarine Pipeline Zone, Cross-Sea Channel Zone, and Dumping Waste Zone should be added as tertiary classification in the other Special Use Zones in the municipal-level classification system. These four marine functional zones have different impacts on the sea area and marine environmental requirements, and thus, it was necessary to clearly define their functions. As a result, 4 new Sewage Discharge Zones, 27 new Submarine Pipeline Zones, 10 new Cross-sea Channel Zones, and 1 new Dumping Waste Zone was defined in the Putian City MFZ. 
A typical special use zone is the Meizhou Island Second Cross-Sea Channel Zone (Figure 5). Meizhou Island is an important national ocean park, and as the birthplace of Mazu culture, the number of tourists on Meizhou Island has increased over the years. However, the island has only one access path with inadequate capacity considering the rapid growth of passengers and the transportation needs of the islanders. This area is located in the Meizhou Bay Reserved Zone and Meizhou Island Protected Zone in the provincial-level MFZ. To address this access capacity problem, the Meizhou Island Second Cross-Sea Channel Zone was added to the MFZ at the municipal level.

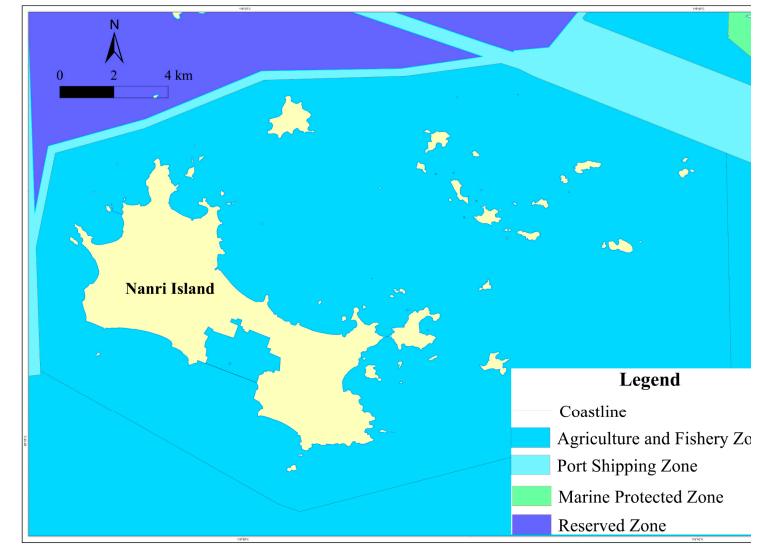

(a) original zoning

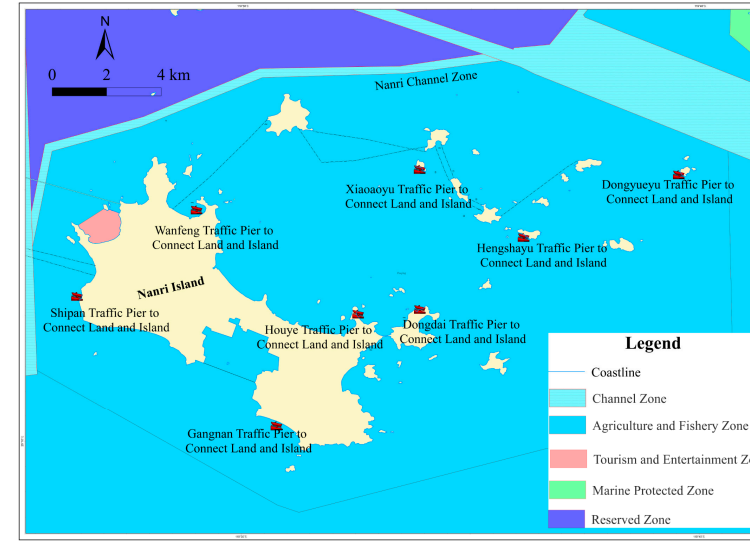

(b) modified zoning

Figure 5. Revised zoning at Meizhou Island: (a) provincial zoning, (b) municipal zoning.

Finally, for the Mineral and Energy Zone, Tourism and Entertainment Zone, Marine Protected Zone, Industrial and Urban Zone, and Reserved Zone, the secondary classification were not divided as there was no identified need to do so.

\subsection{Re-allocation of MFZ Control Indicators at the Municipal Level}

\subsubsection{Sea Reclamation Area Control Indicator}

Sea reclamation area is an important control indicator for coastal cities in the context of urbanization. Table 6 lists the two main types of reclamation areas and their intensities in Putian for the past 10 years (note that the length of the coastline in Putian is $336 \mathrm{~km}$ ). It can be seen that the reclamation area in Putian has increased every year, with an annual growth peak in 2010, increasing by $55 \%$ over the previous year. It can be found in the table that the reclamation area of Putian was $1,888.88 \mathrm{hm}^{2}$ at the end of 2014, and its reclamation intensity index was $R=5.62$.

Table 6. Reclamation area and intensity in Putian from 2005 to 2014.

\begin{tabular}{|c|c|c|c|c|c|c|c|}
\hline \multirow{2}{*}{ Year } & \multicolumn{2}{|c|}{ Industrial Use } & \multicolumn{2}{|c|}{ Transportation } & \multirow{2}{*}{$\begin{array}{c}\text { Total Increase } \\
\text { in Reclamation } \\
\text { Area }\left(\mathrm{hm}^{2}\right)\end{array}$} & \multirow{2}{*}{$\begin{array}{c}\text { Total } \\
\text { Reclamation } \\
\text { Area } S_{\mathrm{T}}\left(\mathrm{hm}^{2}\right)\end{array}$} & \multirow{2}{*}{$\begin{array}{c}\text { Intensity } \\
R \\
\left(\mathrm{hm}^{2} \cdot \mathrm{km}^{-1}\right)\end{array}$} \\
\hline & No. & $\begin{array}{c}\text { Area } \\
\left(\mathrm{hm}^{2}\right)\end{array}$ & NO. & $\begin{array}{c}\text { Area } \\
\left(\mathrm{hm}^{2}\right)\end{array}$ & & & \\
\hline 2005 & 1 & 47.93 & 0 & 0.00 & 47.93 & 223.67 & 0.67 \\
\hline 2006 & 2 & 80.47 & 0 & 0.00 & 80.47 & 304.14 & 0.91 \\
\hline 2007 & 0 & 0.00 & 5 & 98.72 & 98.72 & 402.86 & 1.20 \\
\hline 2008 & 2 & 88.62 & 1 & 37.32 & 125.94 & 528.80 & 1.57 \\
\hline 2009 & 4 & 74.66 & 4 & 140.01 & 214.67 & 743.47 & 2.21 \\
\hline 2010 & 11 & 319.61 & 4 & 100.90 & 420.51 & 1163.98 & 3.46 \\
\hline 2011 & 5 & 88.86 & 5 & 87.85 & 176.72 & 1340.69 & 3.99 \\
\hline 2012 & 4 & 136.09 & 1 & 44.00 & 180.09 & 1520.78 & 4.53 \\
\hline 2013 & 5 & 180.65 & 1 & 1.51 & 182.16 & 1702.94 & 5.07 \\
\hline 2014 & 8 & 185.94 & 0 & 0.00 & 185.94 & 1888.88 & 5.62 \\
\hline
\end{tabular}


First, according to the scale of RII in Table 3, it can be seen that the reclamation intensity in Putian was within Grade I; therefore, the reclamation pressure was low, and the development potential was large. Therefore, based on the reclamation potential assessment model, the reclamation potential in Putian was:

$$
\mathrm{P}=50 \mathrm{hm}^{2} \cdot \mathrm{km}^{-1} \times 336 \mathrm{~km}-1888.88 \mathrm{hm}^{2}=14911.12 \mathrm{hm}^{2} .
$$

Next, according to the historical data of the region used for the linear regression analysis (shown in Table 7 and Figure 6), the secondary analysie of the fitting results have a better fit than the linear analysis when compared to the experimental data, with an $\mathrm{R}^{2}$ value of 0.979 . Therefore, the regression equation was calculated as:

$$
\mathrm{Y}=5.777 \mathrm{X}^{2}+137.822 \mathrm{X}+1.550,
$$

where $Y$ is the estimated reclamation area, $X$ is the change in time (the order), and the order $\left(X_{2005}\right.$, $\left.X_{2006}, \cdots, X_{2014}, \cdots\right)$ was $1,2, \cdots, 10 \cdots$. If the reclamation potential $(P)$ is fully utilized, the total time required for reclamation is 40 years. The reclamation area $\left(S_{1}\right)$ was thus estimated to be $3686.44 \mathrm{hm}^{2}$ in 2020 .

Table 7. Reclamation model summary and parameter estimates.

\begin{tabular}{ccccccccc}
\hline & \multicolumn{4}{c}{ Model Summary } & \multicolumn{3}{c}{ Estimation of Parameter } \\
\hline Equation & $\mathrm{R}^{2}$ & $\mathrm{~F}$ & $\mathrm{df}_{1}$ & $\mathrm{df}_{2}$ & Sig. & Constant & $\mathrm{b}_{1}$ & $\mathrm{~b}_{2}$ \\
Linear & 0.973 & 328.396 & 1 & 8 & 0.000 & -125.455 & 201.359 & \\
Secondary & 0.979 & 815.320 & 2 & 8 & 0.000 & 1.550 & 137.822 & 5.777 \\
\hline
\end{tabular}

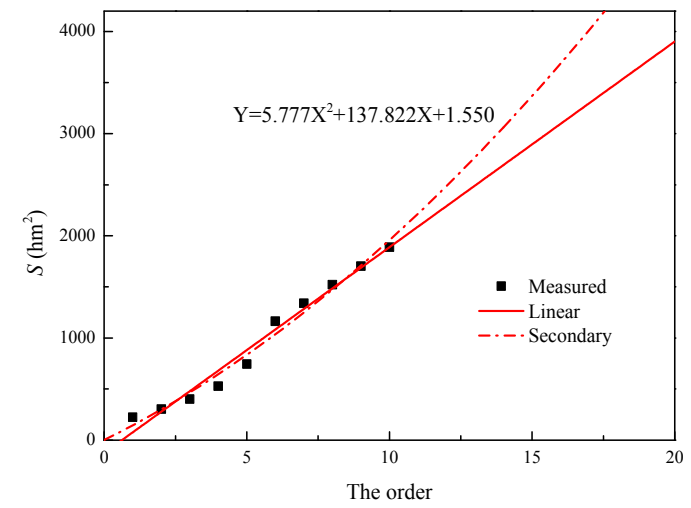

(a)

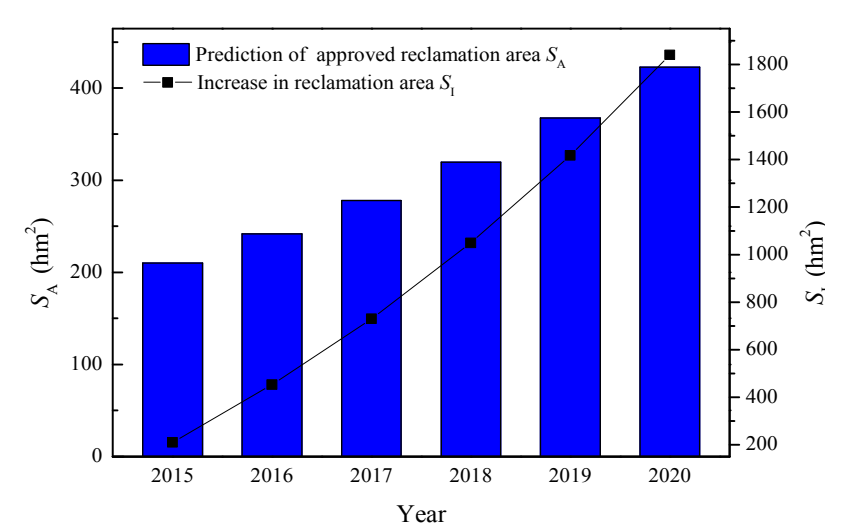

(b)

Figure 6. Total reclamation area in Putian City predicted by two methods: (a) the reclamation potential assessment method and (b) the proportional growth method.

Finally, according to the proportional growth method, the added value of the reclamation area was estimated by reference to the reclamation confirmation projects approved by Putian City in 2012 to 2014, showing an approved reclamation area of $180.09 \mathrm{hm}^{2}$ in $2012,182.16 \mathrm{hm}^{2}$ in $2013,185.94 \mathrm{hm}^{2}$ in 2014 , and an average value of $182.73 \mathrm{hm}^{2} / \mathrm{yr}$. The approved reclamation area thus increased annually by $15 \%$. The estimated reclamation area for 2015 to 2020 was accordingly calculated and is shown in Figure 6, which indicates that the total reclamation area would increase by $1839.49 \mathrm{hm}^{2}$ by 2020 , at which time the total reclamation area $\left(S_{2}\right)$ in Putian would be $3728.37 \mathrm{hm}^{2}$.

The value predicted by the reclamation potential assessment method is $3686.44 \mathrm{hm}^{2}$ (within $R<$ 50 be the control value), while that using the proportional growth method is $3728.37 \mathrm{hm}^{2}$, which is quite close, with a difference of only $41.93 \mathrm{hm}^{2}$. Their average value was taken as the allowed value of the reclamation area. Therefore, an integer value, $3700 \mathrm{hm}^{2}$ was taken as the control value of the total amount of reclamation area. 


\subsubsection{Fishery Farming Area Control Indicator}

The fishery farming area is also an important control indicator as it is closely related to marine resource utilization. According to the historical area data for fishery farming in Putian in the last 10 years (Table 8), the yield and area of fishery farming has been increasing on a yearly basis, but the unit yield is stable at around $29 \mathrm{t} \cdot \mathrm{hm}^{2}$.

Table 8. Fishery farming production and area statistics in Putian from 2005 to 2013.

\begin{tabular}{cccc}
\hline Year & $\begin{array}{c}\text { Fishery Farming } \\
\text { Production (t) }\end{array}$ & $\begin{array}{c}\text { Fishery Farming } \\
\left.\text { Production Area } \mathbf{( h m}^{\mathbf{2}}\right)\end{array}$ & Output Per Unit (t.hm $\left.\mathbf{~}^{\mathbf{}}\right)$ \\
\hline 2003 & 479,306 & 16,324 & 29.3620 \\
2004 & 489,201 & 16,404 & 29.8221 \\
2005 & 513,561 & 17,858 & 28.7580 \\
2006 & 533,901 & 19,002 & 28.0971 \\
2007 & 551,822 & 18,387 & 30.0115 \\
2008 & 529,347 & 18,246 & 29.0117 \\
2009 & 551,802 & 18,907 & 29.1851 \\
2010 & 567,950 & 19,544 & 29.0601 \\
2011 & 569,141 & 19,754 & 28.8114 \\
2012 & 587,649 & 19,851 & 29.6030 \\
2013 & 627,700 & 20,974 & 29.9275 \\
\hline
\end{tabular}

A regression function model was then established based on the statistical data shown in Table 8 . As can be seen in Figure 7 and Table 9, the secondary curve cannot be fitted, while the linear analysis of the fitting results provides a better fit, with an $\mathrm{R}^{2}$ value of 0.877 , indicating a good degree-of-fit between the predicted curve and actual values. Because the development trend of aquaculture sea demand is a linear growth trend, the fishery farming area has been slowly increasing annually. Further, its unit output has been stable for the past 10 years; however, it is expected that Putian will continue to grow steadily for the next few years. Therefore, a linear curve analysis can be used to predict the trend of medium- and long-term aquaculture sea demand in Putian City. According to the regression analysis, the regression equation was determined to be:

$$
\mathrm{Y}=403 \mathrm{X}+16241.182
$$

where $Y$ denotes the predicted value of the fishery farming area, $X$ denotes the change in time (the order), and the order $\left(X_{2003}, X_{2004}, \cdots, X_{2013}, \cdots\right)$ was $1,2, \cdots, 11 \cdots$.

The standard deviation of Equation ( 8$)$ is $S=527.036$. According to the results of the regression analysis, the area of fishery farming in $2020(X=18)$ was estimated to be $23,495.182 \mathrm{hm}^{2}$. According to the total control data for the fishery farming area in the Fujian MFZ at the provincial level, the average fishery farming distribution area of the five coastal cities in the province is $30,500 \mathrm{hm}^{2}$, which was higher than the predicted value [30].

Because fishery farming is an important sector of the marine economy in Putian, a sufficient area should be reserved for such activities with the objective of continuing to develop the fisheries industry in the future. Therefore, an integer value, $24,000 \mathrm{hm}^{2}$, was taken as the control value of the area of the fishery farming zone.

Table 9. Model summary and parameter estimates.

\begin{tabular}{cccccccc}
\hline & \multicolumn{3}{c}{ Model Summary } & \multicolumn{3}{c}{ Estimation of Parameter } \\
\hline Equation & $\mathrm{R}^{2}$ & $\mathrm{~F}$ & $\mathrm{df}_{1}$ & $\mathrm{df}_{2}$ & Sig. & Constant & $\mathrm{b}_{1}$ \\
Linear & 0.864 & 64.316 & 1 & 9 & 0.000 & $16,241.182$ & 403.000 \\
\hline
\end{tabular}




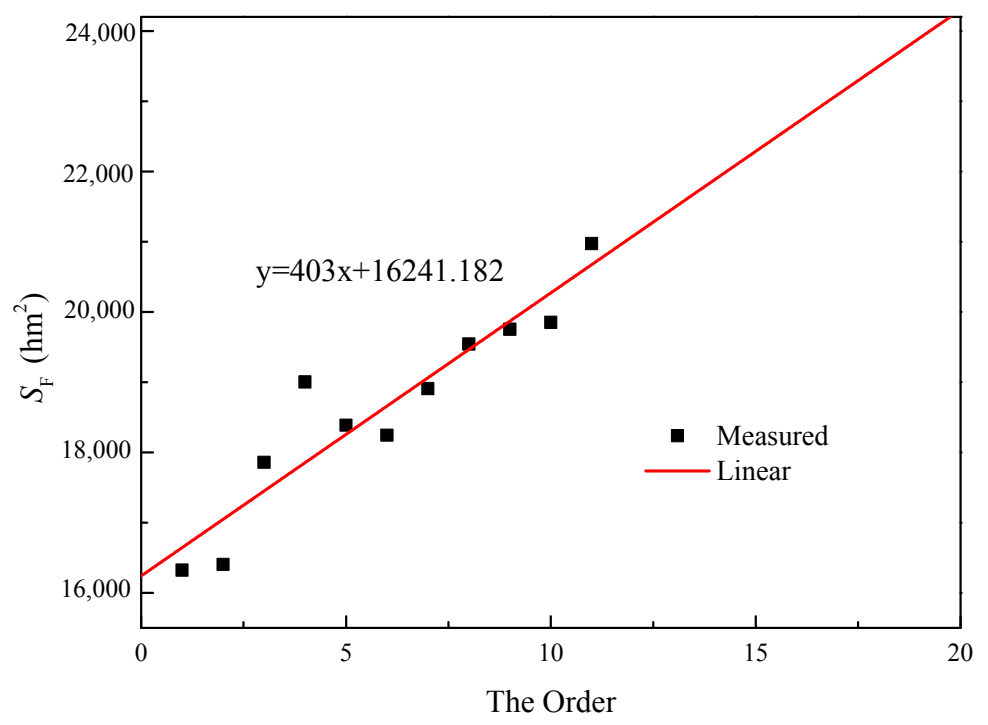

Figure 7. Prediction curve of fishery farming area.

\section{Discussion}

\subsection{Coordinated Solution of the MFZ Classification System at the Provincial and Municipal Levels}

The ocean is an important part of China's domain and it has completely different properties from the land. Reflecting the unique characteristics of the ocean is a considerable challenge. The use of a scientific and comprehensive MFZ indicator classification system can address this challenge [31,32]. The MFZ classification system should theoretically cover all aspects of marine development, utilization, and governance; it should also correspond to the categories identified in the SAU classification so that the requirements of integrated marine management can be satisfied [30]. Furthermore, the establishment of such classification systems must be continuously re-evaluated to reflect scientific and technological progress as well as emerging marine industries $[33,34]$.

To improve the MFZ of Putian City in this case study, we propose adding a fourth secondary classification, Traffic Pier to Connect Islands to the Mainland Zone, in the primary Port Zone and a set of tertiary classifications, Sewage Zone, Cross-Sea Channel Zone, Submarine Pipeline Zone, and Dumping Zone, in the primary other Special Use Zone. The remaining primary functional zones were not further divided except for the addition of a secondary classification Fishery Infrastructure Zone to satisfy the requirements of developing fishery infrastructure.

\subsection{Re-allocation Solution of MFZ Control Indicators in MFZ at the Provincial and Municipal Levels}

As an important basic method of marine management in China, the control system constitutes the core of MFZ, playing an important role in ensuring the realization of MFZ objectives. The control system primarily consists of text control, map control, indicator control, and entire process control of the SAU [35,36]. Among these forms of control, the indicator control, which is a quantifiable control value, plays an important role in controlling the scale and intensity of the SAU, and it can adjust the proportion of a particular SAU and the type of sea area development and utilization mode. This is beneficial for guiding the actual management and operation of the MFZ system. However, the development and utilization of the ocean is not evenly distributed in space. Each city has different development priorities that operate over different time periods considering different location-specific conditions. Therefore, each indicator cannot be calculated as an average for all cities. As a result, it is considerably difficult to rationally re-allocate control indicators determined according to the MFZ at the provincial level to specific needs at the municipal level [37].

In response to these issues, this paper proposed a mathematical model to solve the re-allocation problem of control indicators for sea reclamation, fishery farming, aquaculture, and other marine 
activities that calculates the demand for each SAU according to the demand for a certain type of marine activity in the past and then considers SAU planning objectives for the future [38]. Development trends can then be analyzed to perform simulations that inform predictions for future SAU requirements. Finally, the control values for target years can be obtained and the control indicator can be divided as required in the MFZ at the municipal level. Additionally, we recommend classifying the functional zone types according to the degree of change allowed according to the natural attributes of the sea area and then formulating indicator standards for different functional zone types to achieve a trade-off between marine development/utilization and resource protection. Furthermore, we deemed that the analyzed control values are influenced by macro-factors from the perspective of marine functional zoning, such as economic development (temporal-related) and local natural resource conditions (spatial-related). Here, we assumed that these control values are less affected by other factors.

\section{Conclusions}

We proposed a revised marine functional zoning classification system and control indicator re-allocation to improve the coordination of MFZ activities at the provincial and municipal level, and then, we demonstrated its effectiveness using the case study of the coastal city of Putian, China. Based on a survey of experts at the provincial and municipal levels, we developed a revised classification system with 8 primary classifications and 23 secondary classifications, including the addition of the Traffic Pier to Connect Islands to the Mainland Zone as a fourth secondary classification within the Port Zone and refining the other Special Use Zone into 4 tertiary-classification basic marine functional zones. We also applied a mathematical model to re-allocate two control indicators regarding sea reclamation and fishery farming areas using data at the municipal level. The results of this study showed that the proposed coordination of an MFZ classification system and re-allocation of control indicators for MFZ at the provincial and municipal levels could realize effective and reasonable coordination of MFZ revisions. The results can also be used to provide reference for MFZ revisions at the provincial and municipal levels in other regions of China. Furthermore, other maritime countries can learn from China's MSP experiences and adopt similar concepts for the coordination of MFZ revisions at different levels of authority, thereby protecting their natural environment and service functions through continuous and cyclical improvements in the MSP process.

Author Contributions: Conceptualization, F.H., Y.L. and J.H.; Data curation, R.Z.; Formal analysis, Y.L., H.L. and R.Z.; Funding acquisition, F.H.; Investigation, F.H., Q.C. and J.L.; Methodology, F.H., Y.L., R.Z. and J.H.; Project administration, Y.L.; Resources, F.H.; Visualization, Y.L. and R.Z.; Writing—original draft, Y.L. and H.L.; Writing-review \& editing, F.H. and J.H.

Funding: This study was supported by the Ministry of Natural Resources, People's Republic of China (grant no. HD01-190501).

Acknowledgments: Our authors express sincerest thanks to the experts and managers who provided input to this research.

Conflicts of Interest: The authors declare no conflict of interest.

\section{Appendix A}

Questionnaire for Revision of Marine Functional Zoning at Putian City

Dear experts,

As you know, marine functional zoning (MFZ), as an implementation of MSP in China, is one of the three major systems defined in the Law of the P.R.C. on the Administration of Sea Area Use. Owing to the promulgation of the National Marine Functional Zoning in 2012, the MFZ is being revised at the provincial and municipal levels in coastal cities in China. Our research is focused on revising the MFZ in Putian City in 2013. Therefore, this survey aims to obtain your suggestions for the revision of the MFZ in Putian City and the coordination of MFZ at the provincial and municipal levels. 


\section{Part 1}

Your Name:

Position:

Research field:

Duration of relevant employment:

Part 2

Q1: What are the main problems regarding the coordination of revisions to marine functional zoning at the provincial and municipal levels?

Q2: What are the inadequacies of the classification system of the current MFZ and feasible improvements?

Q3: What are the specific functional patches that must be revised, added, or deleted for the revised MFZ at Putian City?

Q4: How should MFZ control indicators be reallocated at the provincial and municipal levels?

\section{Part 3}

Have you studied MFZ or MSP topics, and could you talk us through your experience? (If possible, our researchers will interview you face-to-face).

\section{References}

1. Fanny, D.; Charles, N.E. International Workshop on Marine Spatial Planning, UNESCO, Paris, 8-10 November 2006. Mar. Policy 2007, 31, 582-583.

2. Douvere, F.; Maes, F.; Vanhulle, A.; Schrijvers, J. The role of marine spatial planning in sea use management: The Belgian case. Mar. Policy 2007, 31, 182-191. [CrossRef]

3. Douvere, F. The importance of marine spatial planning in advancing ecosystem-based sea use management. Mar. Policy 2008, 32, 762-771. [CrossRef]

4. Mei, H. Great Barrier Reef ocean park and Australian marine protected area construction. Wetl. Sci. Manag. 2012, 8, 29-31.

5. Zhang, Y.F.; Zhang, Z.K.; Zhang, J.; Chen, H.Y. Marine spatial planning research progress in European and American countries. Ocean News 2013, 32, 352-360. (In Chinese)

6. Rivera, A.; Gelcich, S.; García-Flórez, L.; Acuña, J.L. Social attributes can drive or deter the sustainability of bottom-up management systems. Sci. Total Environ. 2019, 690, 760-767. [CrossRef]

7. Toonen, R.J.; Andrews, K.R.; Baums, I.B.; Bird, C.E.; Concepcion, G.T.; Daly-Engel, T.S.; Eble, J.A.; Faucci, A.; Gaither, M.R.; Iacchei, M.; et al. Defining boundaries for ecosystem-based management: A multispecies case study of marine connectivity across the Hawaiian archipelago. J. Mar. Biol. 2011, 2011, 460173. [CrossRef]

8. Shi, L. Spatial planning and management of coastal and ocean in the United States. Land Resour. Inf. 2011, 12, 11-13.

9. Feng, R.; Chen, X.; Li, P.; Zhou, L.; Yu, J. Development of China's marine functional zoning: A preliminary analysis. Ocean Coast. Manag. 2016, 131, 39-44. (In Chinese) [CrossRef]

10. Wang, J. A Number of Theoretical Studies on Marine Functional Zoning. Ph.D. Thesis, Ocean University of China, Qingdao, China, 2011. (In Chinese).

11. The National Marine Functional Zoning (2011-2020). The State Council. 2012. Available online: http: //gc.mnr.gov.cn/201806/t20180615_1796945.html (accessed on 10 September 2019). (In Chinese)

12. Li, X.H. Brief analysis of international marine spatial planning. China Sci. Technol. Overv 2015, 2, $15-17$. (In Chinese)

13. Agardy, T.; Sciara, G.N.D.; Christie, P. Mind the gap: Addressing the shortcomings of marine protected areas through large scale marine spatial planning. Mar. Policy 2011, 35, 226-232. [CrossRef] 
14. Dahl, R.; Unesco, P. Marine Spatial Planning: A Step-by-Step Approach Toward Ecosystem-Based Management; United Nations Educational, Scientific and Cultural Organization (UNESCO): Paris, France, 2009.

15. Gilliland, P.M.; Dan, L. Key elements and steps in the process of developing ecosystem-based marine spatial planning. Mar. Policy 2008, 32, 787-796. [CrossRef]

16. Li, S.Y.; Miao, F.M.; Wang, Q.M. Discussion on classification system of marine functional zoning. Mar. Dev. Manag. 2010, 6, 73-79.

17. Wang, Q.; Li, J.; Tian, H.J. Study on the determination of controlling indicators for marine functional zoning in Tianjin. Mar. Environ. Sci. 2014, 3, 451-454.

18. D'Avray, L.T.D.V.; Ami, D.; Chenuil, A.; David, R.; Féral, J.-P. Application of the ecosystem service concept at a small-scale: The cases of coralligenous habitats in the North-western Mediterranean Sea. Mar. Pollut. Bull. $2019,138,160-170$.

19. Jacobo, S.M.; Ileana, E.; Leonardo, O.L. Distribution, uses, and anthropic pressures on reef ecosystems of Mexico. Ocean Coast. Manag. 2018, 165, 39-51.

20. Li, Y.Z.; Fluharty, D.L. Marine protected area networks in China: Challenges and prospects. Mar. Policy 2017, 85, 8-16. (In Chinese) [CrossRef]

21. Strand, J.; Carson, R.T.; Navrud, S.; Ortiz-Bobea, A.; Vincent, J.R. Using the Delphi method to value protection of the Amazon rainforest. Ecol. Econ. 2017, 131, 475-484. [CrossRef]

22. Ho, L.W.; Lie, T.T.; Leong, P.T.; Clear, T. Developing offshore wind farm siting criteria by using an international Delphi method. Energy Policy 2018, 113, 53-67. [CrossRef]

23. Fujian Province Marine Functional Zoning (2011-2020). The State Council. 2012. Available online: http://www.gov.cn/zwgk/2012-10/16/content_2244752.htm (accessed on 10 September 2019). (In Chinese)

24. Qi, Y.; Wei, X.; Wang, H.J.; Liang, L.; Zhao, M.; Hu, H.; Yan, S.Q.; Feng, R.Y. Coastline investigation and evaluation and natural coastline retention rate estimation in Tangshan based on marine functional zoning. In Proceedings of the Oceans 2016, Shanghai, China, 10-13 April 2016. (In Chinese).

25. Liu, Y.; Feng, A.P. Method investigation of the regional recalamation area demands forecasting analysis. Chin. Fish. Econ. 2011, 29, 92-97. (In Chinese)

26. Huang, F.M.; Yu, D.S.; Wang, C.S. Applications of reclamation intensity index to sea reclamation in Gulf Area. J. Subtrop. Res. Environ. 2013, 8, 10-14. (In Chinese)

27. Yang, K.J.; Li, J.L.; Xu, L.H.; Yuan, Q.X.; Liu, Y.C. Spatial-temporal characteristics of flat reclamation in Zhejiang Province, China in the past 20 years. Mar. Sci. Bull. 2018, 20, 58-72. (In Chinese)

28. Qian, J.; Chen, L.H.; Feng, W.H.; Xiang, Y.Y.; Wang, F.Z. Analysis of reclamation intensity and environmental impact in Jiaojiang estuary. Mar. Dev. Manag. 2018, 35, 64-68. (In Chinese)

29. Parker, S.R.; Truscott, J.; Harpur, C.; Murphy, S.D. Exploring a resilience-based approach to spatial planning in Fathom Five National Marine Park, Lake Huron, Canada, using Marxan with zones. Nat. Areas J. 2015, 35, 452-464. [CrossRef]

30. Stamoulis, K.A.; Delevaux, J.M.S. Data requirements and tools to operationalize marine spatial planning in the United States. Ocean Coast. Manag. 2015, 116, 214-223. [CrossRef]

31. Liu, B.Q.; A, D.; Guan, D.M. Framework design of Chinese marine functional zoning in 2011-2020. Mar. Environ. Sci. 2014, 3, 3441-3445. (In Chinese)

32. Fang, Q.H.; Ma, D.Q.; Zhang, L.Y.; Zhu, S.Q. Marine functional zoning: A practical approach for integrated coastal management (ICM) in Xiamen. Ocean Coast. Manag. 2018. [CrossRef]

33. Lu, S.B. Strengthen the legal system of the management of the sea areas use. Mar. Dev. Manag. 1999, 1, 17-20. (In Chinese)

34. Fang, Q.; Zhang, R.; Zhang, L.; Hong, H. Marine functional zoning in China: Experience and prospects. Coast. Manag. 2011, 39, 656-667. [CrossRef]

35. Wang, J.T.; Liu, B.Q. Study on the control system of marine functional zoning. Mar. Bull. 2011, 30, 371-376. (In Chinese)

36. Liu, S.F.; Xu, W.; Hou, Z.Y.; Yue, Q. Study on the management and control system of marine functional zoning. Mar. Environ. Sci. 2014, 3, 455-458. (In Chinese) 
37. Lu, W.H.; Liu, J.; Xiang, X.Q.; Song, W.L.; McIlgorm, A. A comparison of marine spatial planning approaches in China: Marine functional zoning and the marine ecological red line. Mar. Policy 2015, 62, 94-101. [CrossRef]

38. Alleway, H.K.; Thurstan, R.H.; Lauer, P.R.; Connell, S. Incorporating historical data into aquaculture planning. ICES J. Mar. Sci. 2016, 73, 1427-1436. [CrossRef]

(C) 2019 by the authors. Licensee MDPI, Basel, Switzerland. This article is an open access article distributed under the terms and conditions of the Creative Commons Attribution (CC BY) license (http://creativecommons.org/licenses/by/4.0/). 